\title{
Surface Water Quality of Chittagong University Campus, Bangladesh
}

\author{
M.S. Mahmud ${ }^{1}$, M. Islam ${ }^{2}$, N. Hossain ${ }^{3}$, M.G. Kibria ${ }^{4}$ and M. Alamgir ${ }^{5}$ \\ 1, 2, 3, 4,5 Department of Soil Science, University of Chittagong, Chittagong 4331, Bangladesh
}

\begin{abstract}
Some important characteristics of surface water quality of Chittagong University campus, Bangladesh were evaluated for use in domestic, industrial, agriculture, recreation and aquaculture purposes. Fifteen water samples were collected and analyzed in the laboratory of the Department of Soil Science of the University of Chittagong. The study revealed that most physical parameters and inorganic elements are not a serious problem for the water bodies of Chittagong University campus. On the basis of sample analysis it can be said that the surface water of Chittagong University campus is suitable for common uses.
\end{abstract}

Key words: Water quality, Chittagong University, Bangladesh.

\section{Introduction}

Water is the important constituent of life support system. No one can live and even dream of life without water. Today, nearly 40 percent of the world's food supply is grown under irrigation, and a wide variety of daily life processes depends on water [1]. The quality of surface waters is a very sensitive issue. Anthropogenic influences (urban, industrial and agricultural activities, increasing consumption of water resources) as well as natural processes (changes in precipitation inputs, erosion, weathering of crustal materials) degrade surface waters and impair their use for drinking, industrial, agricultural, recreation or other purposes $[2,3]$

Water is essential to plant and animal life; it is our best solvent, and it modifies our climate [4]. Water is an indispensable component of the earth environment. Water is not only essential to life but it is the predominant inorganic constituents of living matter, forming in general nearly three quarters of the weight of the living all $[5,6,7]$. Water is not only important because it contributes to plant growth, but also because it is a transporting agent for dissolved materials, nutrients, chemicals and solids $[8,9]$.

The availability of water supply adequate in terms of both quantity and quality is essential to human existence $[5,6]$. Water quality is influenced both by natural and anthropogenic intervention where the former includes the local climate, geology etc. and the latter covers the construction of dams and embankments, agricultural practices, indiscriminate disposal of industrial effluents etc. [6, 10]. Water quality is and will continue to be a major economic and environmental issue. Water quality concerns have often been neglected because good quality water supplies have been plentiful and readily available. The situation is now changing in many areas of the world including Bangladesh $[9,11,12]$. Water quality study is necessary for its proper use. The study of water quality is of much importance in production of crops. This water quality depends on many parameters among which the most important is the presence of the nutrients, responsible for fertility. Water quality refers to the characteristics of water those will influence its suitability for a specific use, i.e., how well the quality meets the need of the user [13].

The main sources of fresh water in Bangladesh are the different surface water bodies including rivers, canals, lakes, ponds and beels. In the Chittagong University campus, the main sources of surface water are ponds and lakes. Chittagong University is a public university situated in the suburban area of Hathazari, Chittagong district, Bangladesh. The university was established in 1966. The campus is $22 \mathrm{~km}$ north of Chittagong city. The University of Chittagong is surrounded by hills, and bisected by a small stream which made this university a famous tourist spot across the country. Currently, it is the third largest University in Bangladesh with more than 20,000 students, more than 800 faculty members and about 2000 office staffs. Most of students, teachers and staffs live in the university campus and use the surface water of the campus for various purposes. This research was aimed at making an assessment of surface water quality of the Chittagong University campus for domestic, irrigation, recreation and aquaculture purposes.

\section{Materials and Methods}

Fifteen (15) water samples were collected from different locations of the university campus. Sampling sites for water were selected as per a sampling technique [14] which represents the entire water bodies. The high-density PVC bottles used for water sampling were thoroughly cleaned by rinsing with $8 \mathrm{M} \mathrm{HNO}_{3}$ followed by repeated washing with water sampled so as to avoid contamination [14]. The sampling bottles were kept air tight and labeled properly for identification. Aeration during sampling was avoided as far as possible. Variable determinants such as temperature, electrical conductivity (EC), $\mathrm{pH}$ and dissolved oxygen (DO) of water samples 
were measured in the spot using thermometer, portable EC meter, $\mathrm{pH}$ meter and DO meter respectively $[14,15]$. Samples collected from the study area were carefully transported to the laboratory, preserved in a refrigerator and were immediately analyzed for finding intended physical and chemical parameters of water.

Analyses of different physical and chemical parameters were carried out in the laboratory of the Department of Soil Science, Chittagong University. The temperature of water samples were measured by the mercury thermometer $\left(0^{\circ}-50^{\circ} \mathrm{C}\right.$ range $)$ immediately after collection by dipping the thermometer in sample for about one minute [7]. Total Suspended Solids (TSS) and Total Dissolved Solids (TDS) were measured gravimetrically [6]. The $\mathrm{pH}$ of water samples were determined directly by a $\mathrm{pH}$ meter taking $50 \mathrm{ml}$ of water sample in a $100 \mathrm{ml}$ clean beaker [16]. The electrical conductivity (EC) of water samples were measured both in spot and in the laboratory directly by Electrical Conductivity meter (EC meter [16]. Micro Kjeldahl's distillation method was followed to determine $\mathrm{NH}_{4}-\mathrm{N}$ contents [16]. Potassium $(\mathrm{K})$, calcium $(\mathrm{Ca})$ and magnesium $(\mathrm{Mg})$ concentration of water samples were measured directly by atomic absorption spectrophotometer [15]. The chloride content of the water samples were determined by Mohr volume method [16].

\section{Result and Discussion}

The physico-chemical characteristics of the water samples of the study area are presented in Table 1 and the chemical constituents of water of the study area are presented in Table 2.

\section{1 Temperature}

Temperature is an important biologically significant factor, which plays an important role in the metabolic activities of the organism. The average temperature of water samples of the study area was approximately $20.6^{\circ} \mathrm{C}$ and in the range of $19.5^{\circ} \mathrm{C}$ to $22.5^{\circ} \mathrm{C}$ (Table 1 ). The temperature of water samples were found suitable for domestic and industrial uses and irrigation purposes $[6,7,17,18]$.

\subsection{Electrical Conductivity (EC)}

The electrical conductivity (EC) of water is an indicator of salinity hazard and gives the total salt concentration in water [19, 20, 21, 22]. Electrical conductivity (EC) values of the water samples ranges from 23$153 \mu \mathrm{S} \mathrm{cm}^{-1}$ (Table 1) with an average value of $83 \mu \mathrm{S} \mathrm{cm}$-1 which are "excellent to good" for irrigation according to Wilcox [19] irrigation water quality classification and surface water quality [17].

\subsection{Dissolved Oxygen (DO)}

The values of Dissolved Oxygen (DO) were found to be moderate in the sampling area having a range of 8.6-9.1 mg/l with an average value of $8.8 \mathrm{mg} / \mathrm{l}$ (Table 1). Water quality of the sampling area regarding DO was found suitable for drinking, domestic, irrigation and industrial purposes [18, 25].

\section{4 Total Dissolved Solids (TDS)}

The Total Dissolved Solid (TDS) in the collected water samples varied from $40 \mathrm{mg} / \mathrm{l}$ to $80 \mathrm{mg} / \mathrm{l}$ (Table 1). The average value was $58.7 \mathrm{mg} / \mathrm{l}$. The TDS values of the sampled water show low concentration of dissolved solids [20, 23, 24] and within permissible limit for utilization [18, 25].

\section{Table 1 Physico-chemical parameters of the surface water of Chittagong University campus}

\begin{tabular}{|c|c|c|c|c|c|c|c|}
\hline Sample No & Location & $\begin{array}{l}\text { Temp. } \\
\left({ }^{\circ} \mathrm{C}\right)\end{array}$ & $\begin{array}{c}\mathrm{EC} \\
(\mu \mathrm{S} / \mathrm{cm})\end{array}$ & $\begin{array}{c}\mathrm{DO} \\
(\mathrm{mg} / \mathrm{l})\end{array}$ & $\begin{array}{l}\text { TDS } \\
(\mathrm{mg} / \mathrm{l})\end{array}$ & $\begin{array}{c}\mathrm{TSS} \\
(\mathrm{mg} / \mathrm{l})\end{array}$ & $\% \mathrm{OM}$ \\
\hline 1 & Biological Science faculty & 21.0 & 95 & 9.1 & 40 & 0.8 & 0.01 \\
\hline 2 & Science faculty & 20.4 & 125 & 8.6 & 80 & 1.2 & 0.02 \\
\hline 3 & Uttara colony & 20.0 & 81 & 8.7 & 80 & 1.2 & 0.04 \\
\hline 4 & East side of Science lounge & 22.5 & 137 & 8.8 & 80 & 0.8 & 0.02 \\
\hline 5 & Hill bottom colony & 21.3 & 128 & 8.9 & 80 & 1.2 & 0.01 \\
\hline 6 & Jangalia-1 & 21.1 & 70 & 8.8 & 40 & 1.2 & 0.02 \\
\hline 7 & Jangalia-2 & 21.5 & 57 & 8.9 & 40 & 1.2 & 0.04 \\
\hline 8 & Botanical Garden-1 & 20.3 & 55 & 8.8 & 40 & 1.2 & 0.03 \\
\hline 9 & Botanical Garden-2 & 19.5 & 64 & 8.8 & 80 & 0.8 & 0.03 \\
\hline 10 & Islamia Colony & 19.6 & 84 & 8.8 & 40 & 1.2 & 0.03 \\
\hline 11 & Gool pukur & 20.1 & 27 & 8.9 & 80 & 1.2 & 0.02 \\
\hline 12 & Science faculty mosque & 20.2 & 153 & 8.8 & 40 & 1.2 & 0.03 \\
\hline 13 & Arts Faculty & 20.5 & 108 & 8.9 & 40 & 0.8 & 0.01 \\
\hline 14 & Rab hall lake & 20.8 & 41 & 8.9 & 80 & 1.4 & Trace \\
\hline 15 & Forestry Institute & 20.0 & 23 & 8.7 & 40 & 1.6 & 0.02 \\
\hline Range & & $19.5-22.5$ & $23-153$ & $8.6-9.1$ & $40-80$ & $0.8-1.6$ & $0-0.04$ \\
\hline Average & & 20.6 & 83 & 8.8 & 58.7 & 1.1 & 0.022 \\
\hline
\end{tabular}




\section{5 Total Suspended Solid (TSS)}

The Total Suspended Solid (TSS) in the collected water samples ranged from $0.8 \mathrm{mg} / \mathrm{l}$ to $1.6 \mathrm{mg} / \mathrm{l}$ (Table 1). The average value was $1.1 \mathrm{mg} / \mathrm{l}$. The TSS concentration recorded in this study was low. There is no authorized standard for TSS, but values below $30.0 \mathrm{mg} / \mathrm{l}$ are generally considered low and values above 30.0 $\mathrm{mg} / \mathrm{l}$ considered high [26].

\subsection{Organic Matter (OM)}

The range of organic matter $(\mathrm{OM})$ content of the water samples was trace to $0.04 \%$ with an average value of $0.022 \%$ (Table 1 ).

\section{$3.7 \mathrm{pH}$}

$\mathrm{pH}$ is a term that is universally used to express the intensity of acid or alkaline condition of a solution. The $\mathrm{pH}$ values of water of study area ranges from 6.39-7.50 (Table 2) with an average value of 6.69, which are within the permissible limit for irrigated agriculture $[18,25]$ and industrial and domestic use [6].

\subsection{Potassium (K)}

From the Table 2, it seems that the concentration of $\mathrm{K}$ found was within permissible limit in all sampling points [18,27]. The average concentration was $2.76 \mathrm{mg} / \mathrm{l}$ having a range of $1.14-5.65 \mathrm{mg} / \mathrm{l}$.

\subsection{Calcium (Ca) and Magnesium (Mg)}

Calcium (Ca) and magnesium $(\mathrm{Mg})$ content of water samples ranged from 0 to $5.83 \mathrm{mg} / \mathrm{l}$ and 0 to 2.37 $\mathrm{mg} / \mathrm{l}$ with an average value of $2.26 \mathrm{mg} / \mathrm{l}$ and $1.68 \mathrm{mg} / \mathrm{l}$ respectively (Table 2). It is evident that the values of $\mathrm{K}$, $\mathrm{Ca}$ and $\mathrm{Mg}$ content of the water samples were within the recommended limits for irrigation, domestic and aesthetic purposes $[18,28]$.

\subsection{Chloride $\left(\mathrm{Cl}^{-}\right)$}

The chloride concentration serves as an indicator of pollution by sewage. The concentration of chloride $\left(\mathrm{Cl}^{-}\right)$was found to be moderate in the sampling area. The Chloride $\left(\mathrm{Cl}^{-}\right)$content of water of the sampling area was suitable for drinking, domestic and irrigation purposes [18, 29, 30].

\subsection{Ammonium $\left(\mathrm{NH}_{4}^{+}\right)$}

The range of $\mathrm{NH}_{4}{ }^{+}$content in the water of Chittagong University ranged from 0.11 to $0.48 \mathrm{mg} / \mathrm{l}$ with an average value of $0.29 \mathrm{mg} / \mathrm{l}$ (Table 2). According to Department of Environment [18], WHO [27] and USEPA [29] the Ammonium $\left(\mathrm{NH}_{4}^{+}\right)$concentration of water of the sampling area was found suitable for drinking, domestic, and irrigation purposes.

Table 2: Chemical constituents of the surface water samples of Chittagong University campus

\begin{tabular}{|c|l|c|c|c|c|c|c|}
\hline Sample No & \multicolumn{1}{|c|}{ Location } & $\mathrm{pH}$ & $\mathrm{K}(\mathrm{mg} / \mathrm{l})$ & $\mathrm{Ca}(\mathrm{mg} / \mathrm{l})$ & $\mathrm{Mg}(\mathrm{mg} / \mathrm{l})$ & $\mathrm{Cl}^{-}(\mathrm{mg} / \mathrm{l})$ & $\mathrm{NH}_{4}{ }^{+}(\mathrm{mg} / \mathrm{l})$ \\
\hline 1 & Biological Science faculty & 7.03 & 2.35 & 3.78 & 2.33 & 160 & 0.12 \\
\hline 2 & Science faculty & 6.48 & 3.79 & 5.83 & 2.37 & 190 & 0.11 \\
\hline 3 & Uttara colony & 6.45 & 2.12 & 0.29 & 1.93 & 190 & 0.27 \\
\hline 4 & East side of Science lounge & 6.48 & 1.93 & 1.20 & 2.21 & 140 & 0.11 \\
\hline 5 & Hill bottom colony & 6.55 & 5.65 & 1.25 & 2.08 & 160 & 0.28 \\
\hline 6 & Jangalia-1 & 6.76 & 1.74 & Trace & 0.73 & 140 & 0.48 \\
\hline 7 & Jangalia-2 & 6.55 & 1.39 & 0.75 & 1.88 & 160 & 0.38 \\
\hline 8 & Botanical Garden-1 & 7.50 & 1.14 & Trace & Trace & 170 & 0.28 \\
\hline 9 & Botanical Garden-2 & 6.61 & 2.14 & 1.45 & 1.75 & 160 & 0.43 \\
\hline 10 & Islamia Colony & 6.64 & 3.49 & 4.89 & 1.90 & 140 & 0.22 \\
\hline 11 & Gool pukur & 6.39 & 1.79 & 1.00 & 0.46 & 170 & 0.45 \\
\hline 12 & Science faculty mosque & 6.91 & 3.42 & 5.47 & 2.30 & 200 & 0.28 \\
\hline 13 & Arts Faculty & 6.49 & 3.91 & 0.23 & 0.61 & 160 & 0.33 \\
\hline 14 & Rab hall lake & 6.54 & 2.59 & 1.34 & 0.71 & 230 & 0.29 \\
\hline 15 & Forestry Institute & $6.39-7.50$ & $1.14-5.65$ & $0-5.83$ & $0-2.37$ & $140-230$ & $0.11-0.48$ \\
\hline Range & & 6.69 & 2.76 & 2.26 & 1.68 & 169 & 0.29 \\
\hline Average & & & & & & & 0.30 \\
\hline
\end{tabular}




\section{Conclusion}

The samples were analyzed for intended water quality parameters following internationally recognized and well established analytical techniques. From the present investigation it was observed that there were no extreme variations of surface water temperature and the ambient temperature. Dissolved Oxygen (DO) of the water of study area is suitable for most of the intended uses. Electrical conductivity (EC) of collected water samples is "excellent to good". The TDS and EC values of the sampled water show moderate concentration of dissolved solids and non-saline water. It is evident that all the values of sodium (Na), potassium (K), calcium $(\mathrm{Ca})$, magnesium $(\mathrm{Mg})$, chloride $(\mathrm{Cl})$ and ammonium $\left(\mathrm{NH}_{4}\right)$ falls under the permissible limit and there were no toxicity problem. Water samples showed no extreme variations in the concentrations of cations and anions. Thus, most of the inorganic elements are not a serious problem in terms of water contamination in Chittagong University campus.

\section{References}

[1] Bangladesh Center for Advanced Studies (BCAS), Pollution Study: Management of Aquatic Ecosystem through Community Husbandry (Dhaka, Bangladesh, 2000).

[2] S.R. Carpenter, N.F. Caraco, D.L. Correll, R.W. Howarth, A.N. Sharpley, V.H. Smith, Nonpoint pollution of surface waters with phosphorus and nitrogen, Ecol Appl 8(3), 1998, 559-568.

[3] H.P. Jarvie, B.A. Whitton, C.Neal, Nitrogen and phosphorus in east coast British rivers: speciation, sources and biological significance, Sci Total Environ, 210-211, 1998, 79-109.

[4] R.L. Doanhue, R.W. Miller and J.C. Shickluna, Soils: An Introduction to Soils and Plant Growth (New Delhi, India, Prentice-Hall of India pvt. Ltd., 1999).

[5] S.E. Manahan, Environmental Chemistry (Boca Raton, USA, CRC Press Inc., 1994)

[6] H.S. Peavy, D.R. Rowe and G. Tchobanoglous, Environmental Engineering (New York, USA, McGraw Hill, 1985).

[7] P.K. Gupta, Methods in Environmental Analysis: Water, Soil and Air (Jodhpur, India, Agrobios, 2000).

[8] J.L. Hatfield and D.L. Karlen, Sustainable Agricultural Systems (Boca Raton, Florida, USA, Lewis Publishers, 1994)

[9] S.Z.K.M. Shamsad, M. S. Islam and M. Q. Hassan, Ground water quality and hydrochemistry of Kushtia district, Bangladesh, J. Asiat. Soc. Bangladesh, Sci. 25 (1), 1999, 1-11.

[10] S.O. Ryding, and W. Rast, The Control of Eutrophication of Lake and Reservoirs. Man and the Biosphere Series Vol. 1 (United Nations Educational, Scientific and Cultural Organization, 1989).

[11] A.A.Rahman, S. Huq and G.R. Conway, Environmental Aspect of Surface Water system of Bangladesh (Dhaka, Bangladesg, The University Press Limited, 2000).

[12] M. S. Islam, M. Q. Hasan and S.Z.K.M. Shamsad, Quality of irrigation water in the Kushtia District of Bangladesh, J. Biol. Sci. 7 (2), 1998, 129-138.

[13] V.E. Hansen, O.W. Israelsen and G.E. Stringham, Irrigation: Principles and Practices (New York, John Wiley and Sons, 1980).

[14] G.R. Chhatwal, M.C. Mehra, M. Sataka, T. Katyal, M. Katyal and T. Nagahiro, Encyclopidia of environmental pollution and its control. Vol. II, water pollution (New Delhi, Anmol Publications, 1992).

[15] A. L. Page, R.H. Miller and D.R. Keeney, Methods of Soil Analysis (ed.), Part 2 (Madison, Wisconsin. USA, American Society of Agronomy \& Soil Science Society of America, 1982).

[16] M.L. Jackson, Soil Chemical Analysis (Englewood Cliffs, N.J. USA, Prentice Hall Inc., 1967)

[17] M.L. Davis and D.A. Cornwell, Introduction to Environmental Engineering (Boston, USA, McGraw Hill, 1998).

[18] Department of Environment, Bangladesh Gazette, No. DA-1 (Ministry of Environment and Forest, Department of Environment, 1997).

[19] L.V. Wilcox, Classification and Use of Irrigation Waters (Wasington, D.C, United States Department of Agriculture. Circ. 969, 1955).

[20] A. M. Michael, Irrigation Theory and Practices (New Delhi, Vikash Publishing House Ltd., 1992).

[21] R. D. Misra and M. Ahmed, Manual of Irrigation Agronomy (New Delhi, Oxford and IBH Publishing Co. Pvt. Ltd., 1987).

[22] N.C. Brady and R.R. Well, The Nature and Properties of Soils (New Delhi, India, Pearson Education Inc., 2002).

[23] L.A. Richards, Diagnosis and Improvement of Saline and Alkali Soils (Washington, D.C., U.S. Department of Agriculture Handbook, Vol. 60, 1954).

[24] D. K. Todd, Ground Water Hydrology (New York, John Willy and Sons Inc., 1980).

[25] UCCC (University of California Committee of Consultants), Guidelines for Interpretations of water Quality for Irrigation (California, U.S.A, Technical Bulletin, University of California Committee of Consultants, 1974).

[26] M. B. Gasim, B.S. Ismail, E. Toriman, S. I. Mir and T. C. Chek, A Physico-Chemical Assessment of the Bebar River, Pahang, Malaysia, Global Journal of Environmental Research, 1 (1), 2007, 07-11

[27] WHO (World Health Organization), Water quality assessments: A guide to the use of biota, sediments and water in environmental monitoring, (Spon, London, 1996).

[28] R.S. Ayres and D. W. Wescot, Water Quality for Agriculture (Rome, FAO Irrigation and Drainage paper no. 29, Food and Organization of the United Nations, 1985).

[29] USEPA (United States Environmental Protection Agency), Drinking Water Quality Standards. United States Environmental Protection Agency, 2000) Available at: http://www.epa.gov/safewater/contaminants/index.html

[30] WHO (World Health Organization), Guidelines for Drinking Water Quality, Vol. 1 Recommendations (WHO, Geneva, 2004). 